\title{
Die ttirkischen Namen der Tore von Konstantinopel.
}

Der vollständige Text der von Preger-Pantchenko, B. Z. XXI 4624, angefuhrten Schrift De portis Cpoleos nominibusque iis a Turcis impositis in der Hs Sinai 1208 lautet:

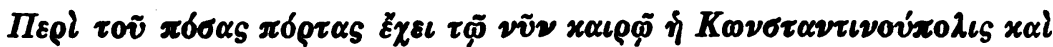

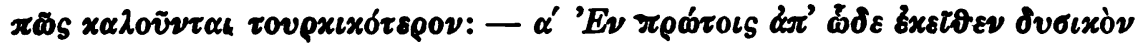

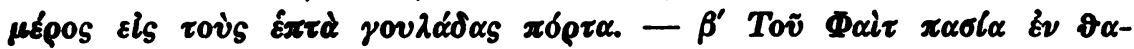

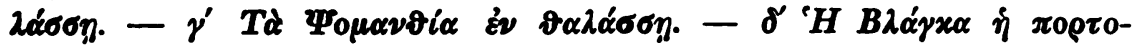

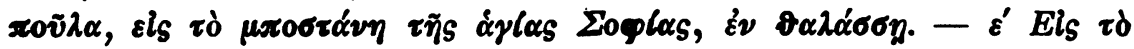

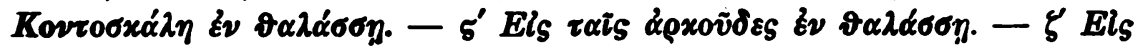

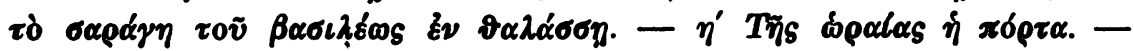

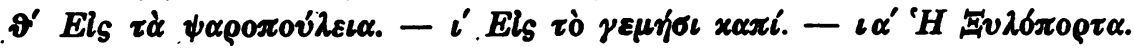

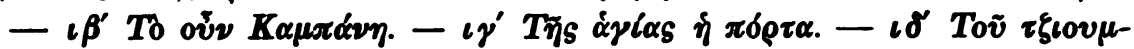

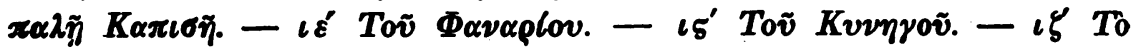

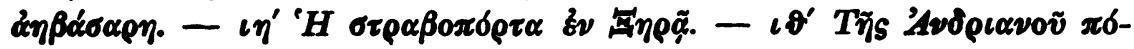

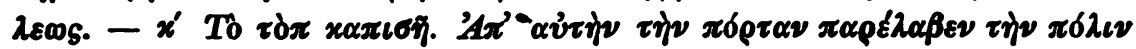

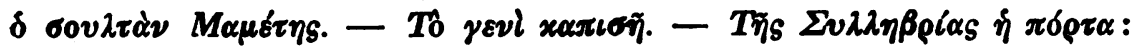

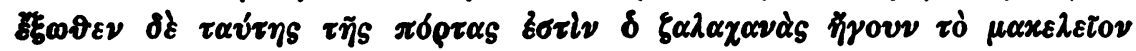

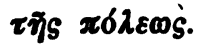

St. Petersburg.

W. Beneschewitsch.

(Manuskript eingelaufen am 1. II. 1914.) 